\title{
Como era bizarro o nosso cinema: a transgressão conservadora de Sady Baby*
}

\author{
Diego Santos Vieira de Jesus**
}

\section{Resumo}

O objetivo deste trabalho é examinar como produções cinematográficas do ator e diretor Sady Baby construíram representações acerca de homens heterossexuais, mulheres, homens homossexuais e travestis. $\mathrm{O}$ argumento central aponta que, ainda que o apelo ao bizarro $e$ ao grotesco representasse resistência à domesticação e à normalização dos corpos, as obras desse diretor reproduziam valores depreciativos em relação a mulheres, homens homossexuais e travestis, enquanto reiteravam padrões de uma virilidade dominante dos personagens masculinos heterossexuais.

Palavras-chave: Sady Baby, Pornochanchada, Transgressão, Cinema Brasileiro, Sexo Explícito.

* Recebido em 23 de novembro de 2017, aceito em 17 de junho de 2019.

** Docente e pesquisador do Programa de Mestrado Profissional em Gestão da Economia Criativa da ESPM-Rio; coordenador do Laboratório de Cidades Criativas da mesma instituição. Rio de Janeiro, RJ, Brasil. dvieira@espm.br / http://orcid.org/0000-0001-6114-7266 
How Bizarre was our Cinema?: the Conservative Transgression of Sady Baby

\begin{abstract}
The purpose of this study is to examine how film productions by actor and director Sady Baby constructed representations about heterosexual men, women, homosexual men and transvestites. The central argument is that, although the appeal to the bizarre and the grotesque represented resistance to the domestication and normalization of bodies, this director's movies reproduced disparaging values towards women, homosexual men and transvestites, while reiterating standards of dominant virility of heterosexual male characters.
\end{abstract}

Keywords: Sady Baby, "Pornochanchada", Transgression, Brazilian Cinema, Explicit Sex 
Durante cerca de vinte anos, a pornochanchada desenvolveu a possibilidade de prazer a partir da imagem em movimento, trazendo os corpos, os desejos e as sexualidades para comporem a prática cinematográfica no Brasil, ainda sob o governo militar. Ao mesmo tempo que oferecia uma resposta ao poder dos agentes do Estado por meio da exploração do prazer, do humor e do deboche, a pornochanchada evidenciava aspectos presentes na sociedade brasileira, mas que permaneciam como temas sensíveis, como traição, diversidade sexual e desejo feminino.

Por seu caráter debochado e erótico, essa produção cinematográfica incomodou setores mais conservadores da sociedade brasileira, que persistiam na necessidade de defenderem os valores morais e os "bons costumes". Embora as primeiras produções do gênero tenham sido desenvolvidas no Rio de Janeiro, ela atingiu seu auge em um terreno fértil do centro de São Paulo, caracterizado pela marginalidade e próximo às redes de transporte, já no fim da década de 1960: a chamada "Boca do Lixo". As produções desenvolveram-se predominantemente nessa área, até que a concorrência do material pornográfico fizesse com que elas gradualmente perdessem força, desde meados da década de 1980, bem como a abertura política esvaziasse o conteúdo desafiador ao regime de diversas de suas produções (Bertolli Filho; Amaral, 2016; Sternheim, 2005). Entretanto, questionando as estruturas conservadoras com seu teor satírico e irônico, a Boca do Lixo contribuiu para a construção da indústria cinematográfica no Brasil ao definir relaçóes de consumo de produtos culturais de baixo custo, que não se alinhavam aos valores eruditos ou elitistas $e$ nem à produção de filmes em grande escala, os quais foram exibidos por todo o país (Amaral, 2016).

A pornochanchada trazia crônicas de costumes como a chanchada brasileira, mas com claras intenções sexuais. A própria adição do prefixo "porno" remetia não somente à malícia, mas à permissividade e à liberação dos costumes no Brasil, trazidas pelos movimentos sociais em pleno regime militar no país. O gênero englobava filmes que abarcavam temáticas sexuais e podiam 
conter enredos satíricos permeados por terror, romance, suspense, paródias de textos literários e religiosos ou de sucessos cinematográficos internacionais, por exemplo. Por meio de uma censura institucional, o regime impunha restrições às insinuações realísticas de sexo nas produções desse gênero, além de criticá-lo por distorcer princípios. Tais restrições contavam com o apoio de instituições como a Igreja Católica e as ligas femininas, de forma que a condenação tinha caráter não somente institucional, mas também de grupos sociais. A fase inicial - softcore - da pornochanchada ressaltava a comédia de costumes explorando a sensualidade e o erotismo, em face da impossibilidade de trazer o sexo explícito por conta da censura. Ela se utilizou da abertura trazida pela revolução sexual do fim da década de 1960 para atender a um novo mercado consumidor, reinventando-se constantemente para burlar a vigilância dos censores na exibição de nudez e na inserção de insinuações de sexo (Simões, 2013). Na década de 1980, a segunda fase - hardcore - atende às demandas por sexo explícito, que revelavam uma necessidade de sobrevivência à pressão externa das produções eróticas $e$ pornográficas e dispensavam estratégias mais sutis utilizadas na primeira fase (Rossini, 2016; Seligman, 2003).

Nesse momento, grande parte dos diretores da segunda fase - que serviram de base para o desenvolvimento da indústria pornográfica brasileira - acaba seguindo um viés cômico e, em termos estéticos, cai em produções de caráter bastante caricatural, com a exploração do escracho e do pastiche entremeados a cenas de sexo explícito, como os filmes do ator e diretor gaúcho Sady Baby. Na busca por competir com a produção internacional, Baby ganhou visibilidade durante a decadência da Boca do Lixo, quando as produções de baixo orçamento se voltavam para o sexo explícito, e foi um dos cineastas que exploraram não só o deboche, mas também aberrações e ousadias. Ele mobilizava práticas sexuais com conteúdo compreendido como "extremo" ou "bizarro", como a zoofilia e as simulações de necrofilia. Ainda que emulassem algumas características da fase softcore da pornochanchada em produções mais explícitas, os filmes hardcore 
de Sady Baby não conseguiram competir com as produções internacionais, que tinham melhor acabamento estético e visual, nem resistir à retração da produção cinematográfica nacional diante da crise econômica e do fim da Empresa Brasileira de Filmes Sociedade Anônima (Embrafilme), no governo de Fernando Collor de Mello (Cruz, 2016a). Desde então, Baby esteve envolvido em uma série de situações controversas. Após boatos de que teria se suicidado saltando da ponte do Rio Uruguai, ele e a namorada foram presos em Caxias do Sul, em 2013. Ele portava documentos falsos e estava desaparecido desde 2008, sob a acusação de ter contratado uma atriz menor de idade para seu último filme (Lucena, 2013).

Em face do caráter controverso de sua obra, com relação ao tratamento das identidades de gênero e das sexualidades, o objetivo deste artigo é examinar como três produções de Sady Baby - "Meninas, virgens e p... (Troca de óleo)", "Emoções sexuais de um jegue" e "No calor do buraco" - construíram representações acerca do homem heterossexual, da mulher, do homem homossexual e da travesti. $\mathrm{O}$ argumento central aponta que, ainda que o apelo ao bizarro $e$ ao grotesco representasse uma resistência à domesticação e à normalização dos corpos, as obras de Sady Baby reproduziam valores depreciativos em relação a mulheres, homens homossexuais e travestis, enquanto reiteravam padrões de uma virilidade dominante dos personagens masculinos heterossexuais. Sustenta-se que, mesmo expondo a possibilidade de fluidez sexual e a flexibilidade das construções de gênero, os filmes não conduziam a uma contestação do aparato de dominação que colocava mulheres, homens homossexuais $e$ travestis em posições de abjeção. Num contexto mais amplo, discute-se também neste artigo que a pornochanchada transcendia a sexploitation norte-atlântica, na medida em que combinava aos elementos vindos dela traços das comédias de costumes cariocas, beneficiava-se de leis de reserva de mercado e desenvolvia relações mais estreitas entre seus filmes e o mainstream. Além disso, ainda que fosse profundamente marcada pelo "olhar masculino" - "male gaze" (Mulvey, 1999), conceito amplamente 
explorado pela literatura feminista -, a pornochanchada - em especial na sua fase mais explícita - veio ainda mais permeada por elementos característicos da cultura brasileira, particularmente em termos do processo criativo, resgatando estereótipos culturalmente específicos, disseminados nesta sociedade, acerca de homens heterossexuais e homossexuais, mulheres e travestis.

\section{Fundamentação teórica}

\section{A pornochanchada e a transgressão conservadora}

Em geral, a pornochanchada é concebida por especialistas em Comunicação Social como um gênero que se aproveitava da lógica do "pão-e-circo", com um apelo à facilidade e à informalidade da linguagem junto aos elementos cômicos, com produções de baixa qualidade técnica e roteiros pouco robustos, mediante o apelo à nudez e ao sexo para o entretenimento das massas. Segundo tais críticos, os filmes em questão esvaíam o olhar crítico da população e atendiam aos interesses de manipulação política das massas pelo governo militar (Freitas, 2004; Lopes, 2012; Sales Filho, 1995). A pornochanchada era contestada pelo Cinema Novo e pela crítica cinematográfica também por sua precariedade técnica (Klanovicz; Corrêa, 2016; Rossini, 2016).

Entretanto, um olhar mais apurado sobre a pornochanchada permite identificá-la como uma produção que questionava aspectos da moralidade defendida pelo governo e setores conservadores, aproximando-se do cotidiano da sociedade brasileira; resultado de influências múltiplas, da chanchada brasileira até o cinema erótico italiano. Ao dialogar intensamente com o grande público, as produções da pornochanchada tornaram-se grandes sucessos de bilheteria, em especial com a transferência das produções para a Boca do Lixo. Ao mesmo tempo, conseguiam funcionar como meios de descompressão diante do autoritarismo e também como exercícios narcísicos, pelos encontros oníricos entre espectadores $e$ atores que 
apareciam nessas produções. Nas narrativas, as estratégias adotadas por personagens masculinos e femininos a fim de conquistarem favores - em especial proporcionadas pelas conquistas de cunho erótico ou sexual - atraíam esses espectadores. Constituíam-se também nessas produções novas formas de sociabilidade, que se conectavam ao cotidiano coletivo e compartilhavam carências vividas nesse contexto. Ainda que diretores $e$ atores da pornochanchada não tivessem o objetivo fundamental de combater o regime militar com as produções cinematográficas, as obras englobavam aspectos de identidade $e$ de comportamento com irreverência, de forma que não se alinhavam com aqueles defendidos oficialmente pelo governo $e$ pelos setores conservadores, os quais buscavam a reeducação social e a promoção da moral e dos "bons costumes".

Driblando a rigidez e a vigilância da censura, $e$ se aproveitando até mesmo do despreparo intelectual dos censores na fiscalização do conteúdo implícito nas obras, a pornochanchada explorava com humor, deboche e erotismo, a desestabilização de padrões tradicionais (Bertolli Filho, 2016). Ao serem alvos da censura em âmbitos regional e federal, as produções da pornochanchada sofriam inúmeros cortes e eram submetidas a uma fiscalização voraz, o que evidenciava a vulnerabilidade de diretores e produtores ante os censores. Tal fiscalização frequentemente acarretava prejuízos à equipe, em especial porque a maior parte dos filmes dependia de retorno de bilheteria para o pagamento dos profissionais envolvidos (Lamas, 2016).

Além da censura horizontal, que vinha de atores que não compunham os poderes públicos, a pornochanchada também era objeto da censura vertical, promovida pelos dispositivos legislativos do Estado. O repertório da pornochanchada funcionou como uma das formas de o governo militar estabelecer um olhar paternalista e elitista sobre o cinema e, ao mesmo tempo, o controle político sobre seus opositores. Nesse sentido, a pornochanchada entrava num espaço de luta político-cultural com a censura, o que fazia com que as polêmicas que atingiam a vida 
privada - representadas nas produções da Boca do Lixo - se tornassem políticas (Klanovicz; Corrêa, 2016). A transgressão estava na exposição de temas considerados tabus na sociedade brasileira - em especial os relacionados a comportamentos, desejos $e$ práticas eróticas e sexuais -, ainda que nem sempre se trouxesse ou se estimulasse uma reflexão crítica sobre essas questões controversas (Amaral, 2016).

Em termos de conteúdo, as obras exploravam o humor de personagens pitorescos que se aproximavam de tipos familiares ao público, a ambiguidade de palavras e trocadilhos nos títulos $e$ roteiros, cenas de nudez e de insinuação de atividades sexuais, $e$ referências a situações cotidianas. Isso fez de muitas delas sucessos de público, ao mesmo tempo que lhes era atribuído o rótulo de "lixo cultural", por grande parte de seus críticos (Carrasco; Oliveira, 2016).

As mulheres, os homens heterossexuais $e$ homossexuais $e$ as travestis na pornochanchada

A "malandragem" do homem heterossexual predominava na maior parte das produções da pornochanchada, sendo ela um meio de se atingir o desfrute dos prazeres da vida, o que não era ofertado pelo universo do trabalho formal. A família era tipicamente concebida como uma instituição opressora por reproduzir valores morais tradicionais, de forma que as afinidades se desenvolviam predominantemente entre grupos de amigos que escapavam às composições familiares tradicionais, as quais limitavam as liberdades individuais de seus integrantes (Bertolli Filho, 2016).

A imagem da mulher vinha constantemente associada à passividade e à dissimulação nas produções da Boca do Lixo, ao passo que a capacidade de ação e de satisfação do sexo oposto, a agressividade $e$ a força física eram frequentemente colocadas como características masculinas. Ressaltar o corpo feminino era uma forma de atrair o público masculino e garantir a receita dos filmes. Coloca-se, nesse sentido, que as produções da 
pornochanchada teriam agido como normatizadores de posições misóginas e patriarcais, além de não questionarem a ordem heteronormativa (Klanovicz; Corrêa, 2016; Rossini, 2016). Ao ser transformada em objeto endereçado a uma audiência predominantemente masculina, a mulher era frequentemente anulada enquanto sujeito e tinha seu papel social recalcado. Seu corpo era fetichizado, o que fortalecia a ideia de que o desejo do homem era guiado pelo ímpeto voyeurista em relação a um corpo que funciona como um espetáculo a ser observado (Gubernikoff, 2009; Kaplan, 1995). Embora a mulher fosse objetificada em grande parte das produções da pornochanchada, é possível afirmar que não foi na totalidade do que assim foi produzido que ela foi submissa às vontades e às imposições masculinas. Ao contrário, em algumas produções, as mulheres mostravam-se ativas, desafiando hierarquias na ordem de gênero e mostrando que tanto elas como os homens desenvolviam iniciativas eróticas, sexuais e funções no mundo do trabalho, como representado nas obras de Carlos Reichenbach. Porém, tais filmes eram uma minoria face ao volume de produções da pornochanchada (Bertolli Filho, 2016). A dominação masculina podia ser percebida por meio da afirmação de honra - por exemplo, ao violentar uma mulher acusada de traição - e da virilidade dos homens, um dever imposto aos homens heterossexuais para, em troca, terem garantidos seus privilégios sociais. O dever de afirmação constante da virilidade advém justamente do receio em reconhecer neles elementos associados ao feminino, como a fragilidade $e$ a vulnerabilidade (Bourdieu, 2003).

Além disso, as relações homossexuais masculinas $e$ femininas também eram exploradas: enquanto as cenas lésbicas eram mais toleradas num contexto machista, a homossexualidade masculina era frequentemente condenada. Houve produções, como "Giselle", que acolheram a diversidade sexual também entre homens, mas tais exemplos são mais raros. Em geral, a travesti era retratada nas obras da pornochanchada a partir de uma imagem caricatural de "bicha louca", uma desviante que vivia em busca de sexo (Pires, 2016). Os personagens masculinos homossexuais 
frequentemente eram apresentados como objetos de deboche, em formas bastante caricaturais. Eles serviam de pretexto para provocar o riso de plateias machistas e homofóbicas, denominados pela literatura especializada como "homopalhaços" (Moreno, 2001; Trevisan, 2000). A passividade sexual daqueles personagens rotulados como "bichas" remetia à posição social inferior destinada às mulheres, ao passo que o mesmo estigma não incidia sobre o homem ativo que mantivesse sua identidade ligada aos elementos definidores da virilidade dominante do "macho", determinados pelas normas sociais (Green, 2000).

Apesar do seu aspecto transgressor, a maior parte das produções da pornochanchada não somente carregava, como também reproduzia estereótipos relacionados ao gênero $e$ às sexualidades, como a permanência do papel ativo e dominante dos homens na relação heterossexual, a compulsão sexual das travestis e a futilidade, a fragilidade e a objetificação das mulheres (Amaral, 2016). O desejo apresentado nas produções da pornochanchada limitava-se frequentemente às representações dominantes, patriarcais e heteronormativas, sem que houvesse efetivamente a subversão de valores mais conservadores e de preconceitos em relação a mulheres $e$ homens homossexuais (Gerace, 2015). É possível entender tais limitações, tendo em vista que o efeito psicológico da pornochanchada era atingir fantasias $e$ despertar mecanismos projetivos dos espectadores, em grande parte homens de baixa renda. Ao mesmo tempo que se explorava o corpo feminino para o deleite masculino, permitia-se àqueles homens a identificação com galãs como David Cardoso, que, embora muitas vezes fossem canastrões, eram valentes, fortes $e$ sexualmente ativos. Desenvolviam-se nas narrativas também situações das quais o público ria por já ter vivido ou presenciado algo semelhante, como as de um marido traído, um conquistador piegas, um homem subitamente impotente durante uma relação sexual e até mesmo capaz de uma aventura sexual esporádica com outro homem ou uma travesti, sem que isso ameaçasse a visão que se tinha dele enquanto "macho", por permanecer no papel ativo e dominador no sexo e na conquista (Freitas, 2004). 
A partir de meados da década de 1980, a abertura política transformou o mercado da pornochanchada, uma vez que, com o arrefecimento da censura, os filmes pornográficos internacionais puderam ser exibidos em cinemas e posteriormente disponibilizados em fitas VHS, com a disseminação dos videocassetes (Bertolli Filho; Talamoni, 2015). Ademais, a pornochanchada começou a concorrer com revistas como Ele \& Ela, Status e Playboy, de forma que, para garantirem sua sobrevivência, muitos diretores começaram a mobilizar mais cenas de sexo e títulos explícitos, dando início a um processo que conduziria gradualmente à criação de uma indústria pornográfica no Brasil.

Após um período em que as fronteiras entre a pornochanchada e a pornografia permaneciam difusas por conta das cenas de sexo explícito, ambas vieram perdendo espaços de exibição em cinemas, diante da mudança do hábito de consumo do espectador que priorizava o VHS em busca de uma maior privacidade para assistir aos filmes. Já na década de 1990, produtoras nacionais focadas em filmes pornográficos começaram a surgir, como As Panteras e Brasileirinhas, e as estrangeiras começaram a recrutar atores locais em suas produções (Padovani, 2016). Em busca de mais lucros, diversos diretores da produção tradicional da pornochanchada migraram para o desenvolvimento de filmes de sexo explícito, diante da liberação da censura (Freitas, 2004). Ademais, a crise econômica que se abateu sobre a sociedade brasileira na década de 1980 levou a uma redução considerável do público de cinema no país, o que conduziu não só ao esgotamento de um modelo estético em face da maior liberdade de expressão diante da redemocratização, mas também do modelo econômico da pornochanchada, que não sobreviveu aos filmes de sexo explícito que vinham dos EUA e da Europa (Abreu, 2000).

Nesse momento de transição para o estabelecimento da indústria pornográfica no Brasil, diretores da segunda fase da pornochanchada - a hardcore - continuavam explorando o universo do humor, enfatizando corpos e situações que 
escapavam às classificações tidas como convencionais ou belas. A representação do bizarro - que herdava aspectos dos espetáculos de aberrações humanas (freak shows) - era sexualizada, espetacularizando situações extremas, radicais ou grotescas (Leite Jr., 2006). O não convencional - frequentemente associado aos discursos médicos, jurídicos ou policiais - ganhava espaço nessas produções, que traziam risos e exibições de corpos em busca de prazer junto a elementos transgressores, na medida em que figuras desviantes como anões, travestis, xifópagas, mulheres muito gordas ou com seios enormes apareciam em cenas de sexo explícito, desafiando visões higienistas e disciplinadoras, que exerciam vigilância permanente sobre os indivíduos (Pelúcio, 2007).

Tais figuras - ligadas à perversidade $e$ à anormalidade constituíam personagens do sexo bizarro, caracterizados pelas múltiplas estéticas do grotesco. As estranhezas comportamentais e físicas - condenadas pelo ímpeto biologizante da sociedade moderna - questionavam, de forma crítica e irreverente, os modelos de corpos educados e disciplinados. Entretanto, na medida em que esses tipos eram mobilizados em cena para o prazer e o riso, eles podiam ser ridicularizados numa forma de entretenimento, que acabava reproduzindo aspectos segregadores da sociedade vigente. Se tais bizarrices resistiam à domesticação $e$ à normalização dos corpos, elas podiam, ao mesmo tempo, reproduzir valores depreciativos em relação a esses mesmos corpos, uma vez que eles eram expostos, mas sem a contestação ao aparato de dominação que os segregava. Nesse sentido, a fase hardcore da pornochanchada parecia não remover tais pessoas do plano da abjeção (Pelúcio, 2007).

\section{A pornochanchada, a "sexploitation"e o "male gaze"}

Em geral, utiliza-se o termo exploitation ("exploração" em português) em referência a alguma obra que busque sucesso financeiro a partir da mobilização de alguma tendência momentânea ou de algum assunto que provoque choque, em 
especial violência e sexo (Cruz, 2016b). O termo - que frequentemente se refere a filmes de baixo orçamento fora do mainstream - remete à ideia de marginalidade, mas frequentemente atrai a atenção de críticos $e$ aponta para produções que são adoradas por fãs (Watson, 1997). Já o subgênero sexploitation faz remissão a produções independentes de baixo orçamento - tendo sido a grande maioria produzida na década de 1960 -, que tinham como objetivo expor situações sexuais não explícitas e nudez gratuita, e eram apresentadas em salas de cinema conhecidas nos Estados Unidos como grindhouses, as precursoras das salas de filmes de sexo explícito a partir da década de 1970 (Gorfinkel, 2008, 2012).

Os filmes de sexploitation sofreram a oposição de grupos conservadores - em especial os religiosos -, uma vez que passavam a ser exibidos em cadeias de cinema cada vez maiores $e$ a incluírem mais cenas de sexo simuladas. Com a pressão de tais grupos, muitas grindhouses nos Estados Unidos foram encerradas e passaram a salas de exibição de filmes de sexo explícito, em especial a partir do fim da década de 1970 e início da década de 1980 (Williams, 2014). O momento coincide com o início da fase explícita da pornochanchada no Brasil.

A pornochanchada é vista por Cruz (2016b) como análoga, em inúmeros aspectos, à sexploitation, uma vez que, como ocorreu com produções semelhantes nos Estados Unidos, no Reino Unido e na Itália, beneficiou-se de vantagens comerciais para a produção de filmes os quais exibiam, inicialmente, cenas de nudez e insinuações de situações sexuais e tinham títulos $e$ sinopses sexualmente sugestivos. Entretanto, como desenvolveu Abreu (1996, 2006), os filmes brasileiros não exibiam apenas o erotismo ou contavam com a influência de filmes italianos divididos em episódios que combinavam humor, malícia e ironia em histórias breves. A pornochanchada brasileira trazia também elementos das comédias de costumes cariocas, as chanchadas, que eram tipicamente vistas como produções vulgares $e$ de reduzido valor artístico. Ainda que houvesse o apelo erótico - que se torna apelo ao sexo explícito a partir da década de 1980 -, a 
crônica de costumes que lidava com a realidade culturalmente específica de grande parte da sociedade brasileira mostrava-se presente.

Além disso, a pornochanchada apresentava outras diferenças em relação à sexploitation que ocorria em diferentes culturas cinematográficas. A relação entre $o$ consumo $e$ a distribuição dos filmes apresenta um diferencial no contexto brasileiro, pois a produção cinematográfica da pornochanchada se beneficiou de leis de reserva de mercado impostas pela Embrafilme para se fortalecer. Em particular na fase softcore da pornochanchada, havia relações mais estreitas entre seus filmes $e$ o mainstream, como fica claro em filmes como "Dona Flor e seus dois maridos" e "A dama do lotação" - continham alta carga erótica e contavam com atores $e$ atrizes do mainstream da produção cultural nacional (Cruz, 2016b). Nesse sentido, a pornochanchada bebeu nas fontes do cinema fora do mainstream como a sexploitation norte-atlântica, mas combinou esses elementos a signos existentes na cultura brasileira - como as chanchadas,$- e$ criou versões próprias que dialogavam tanto com os códigos que embasaram as condições culturalmente específicas de tal experiência estética, como com seus vínculos com a cultura de consumo de imagens eróticas e, posteriormente, de sexo explícito (Abreu, 1996).

Como em muitas produções de sexploitation, a pornochanchada também associa o estereótipo viril à potência muscular e à compulsão sexual, a mulher a um objeto para a satisfação do desejo masculino $e$ os homens homossexuais $e$ as travestis aos trejeitos efeminados e à obsessão por sexo. $\mathrm{O}$ argumento já fora desenvolvido por teóricas feministas como Mulvey (1999), que aponta que a noção de "olhar" (gaze) está relacionada à cultura visual que lida com a forma como as pessoas são apresentadas e vistas pelo público. O "olhar masculino" male gaze - aponta, segundo a autora, que as mulheres nos filmes são geralmente objetificadas e não são as donas do "olhar". Isso ocorre porque o controle da câmera está tipicamente nas mãos de um homem branco heterossexual, que em geral é também a 
condição do público-alvo da maioria dos gêneros do filme. A contribuição singular deste estudo está em apontar que o male gaze que orienta a pornochanchada - em especial na fase do sexo explícito - vem atravessado por elementos típicos da cultura brasileira, tanto em termos do processo criativo, resgatando estereótipos disseminados na sociedade acerca de homens heterossexuais e homossexuais, mulheres e travestis, como se verá adiante, como em termos das condições de possibilidade para a produção, a exemplo das leis de reserva de mercado que favoreciam esse gênero.

\section{Consideraçóes metodológicas}

Como a filmografia de Sady Baby conta com quase 30 produções entre 1984 e 1992, em que esteve como diretor e/ou ator, a coleta dos dados foi feita em três obras dirigidas $e$ estreladas por ele em 1986: "Meninas, virgens e p... (Troca de óleo)"; "Emoções sexuais de um jegue" e "No calor do buraco", os dois últimos dirigidos em parceria com Renato Alves. As obras foram escolhidas por sua popularidade na época do lançamento em face de sua mobilização de formas extremas e grotescas de sexo explícito. O material considerado na coleta abrangeu predominantemente as falas $e$ as ações de personagens. Na apresentação dos resultados, foram também expostas algumas cenas selecionadas dos filmes, pois elas não só contribuem para a sustentação do argumento central, como oferecem maior visibilidade às particularidades históricas do momento em que as obras foram produzidas e veiculadas.

$\mathrm{Na}$ composição da amostra a ser analisada, foram levadas em conta três categorias: 1) a caracterização de homens heterossexuais; 2) a caracterização da mulher; 3) as caracterizações de homens homossexuais e travestis. A partir da definição dessas categorias, as falas e as ações foram alocadas em uma delas, que remetem à forma como identidades de gênero e orientações sexuais foram construídas nas três obras de Sady Baby. 
$\mathrm{Na}$ investigação do conteúdo distribuído nas três categorias, buscou-se, após a seleção e a categorização da amostra, a descrição dos resultados obtidos em cada uma delas $e$ a interpretação desses resultados à luz do suporte teórico-conceitual, que viabiliza o entendimento das características subjetivas, metafóricas ou alegóricas do material (Vergara, 2012). O objetivo foi investigar se, inseridas no contexto da fase hardcore da pornochanchada, as obras de Sady Baby permitiram a contestação de uma ordem patriarcal, misógina e homofóbica ou apenas reforçaram seus aspectos fundamentais.

\section{Resultados}

Segundo Baby, seus filmes retratavam taras e fantasias que as pessoas tinham vergonha de expor. Diante da falta de recursos, ele contava com o improviso de atores sem grande experiência dramática, o que, de certa forma, atribuía mais realismo às cenas. De acordo com o diretor em entrevista a Lucena (2013):

Havia pouco recurso, eu tinha poucos atores, a maioria era gente comum, eles não tinham uma base artística, então eu tinha que ir no improviso pra eles se soltarem mais. Se desse o texto pronto pra eles lerem, ia soar mecânico, então o improviso acaba deixando tudo mais espontâneo. Aquilo era um sonho de criança se realizando, eu nasci pra fazer isso.

Esse "realismo" permeia as categorias selecionadas para a análise. Pode-se dizer que o homem heterossexual é predominantemente construído nas produções de Baby como "malandro" ou um indivíduo dominante na realização de práticas sexuais extremas, características que afirmavam sua virilidade ${ }^{1}$.

1 Cabe destacar que esse elemento aparece também em outras obras de Sady Baby que não foram examinadas neste estudo. Em "Ônibus da Suruba", por exemplo, seu personagem tem uma fala que vangloria a "malandragem" em relação ao universo do trabalho e reitera a posição dominante como forma de 
Em "No calor do buraco" e "Emoções sexuais de um jegue", os personagens masculinos são espertos, violentos $e$ aparecem envolvidos não apenas em cenas de ação - que reforçam as ideias de coragem e força associadas à virilidade -, mas também em práticas como a zoofilia, o estupro e a necrofilia (Lucena, 2013). Nessas cenas, o personagem principal - em geral representado pelo próprio Baby -, aparece em situações de dominação, obrigando alguma pessoa - tanto homens como mulheres - a manter relações sexuais com terceira(o)s ou até mesmo com animais, por meio da coerção e em geral sob a mira de uma arma. Tal dominação é frequentemente reafirmada com a satisfação dos personagens masculinos com a morte alheia (Mendes, 2007). No início de "No calor do buraco", por exemplo, um homem tenta estuprar a namorada do protagonista, interpretado por Baby. Quando o personagem principal percebe isso, faz uma artimanha ao amarrar o gatilho da espingarda que carrega ao pênis do estuprador, que, ao excitar-se quando vê a garota nua, provoca um disparo contra a sua própria cabeça. A artimanha preparada pelo protagonista e a satisfação dele com a morte do estuprador ficam nítidas na sequência de imagens da Figura 1.
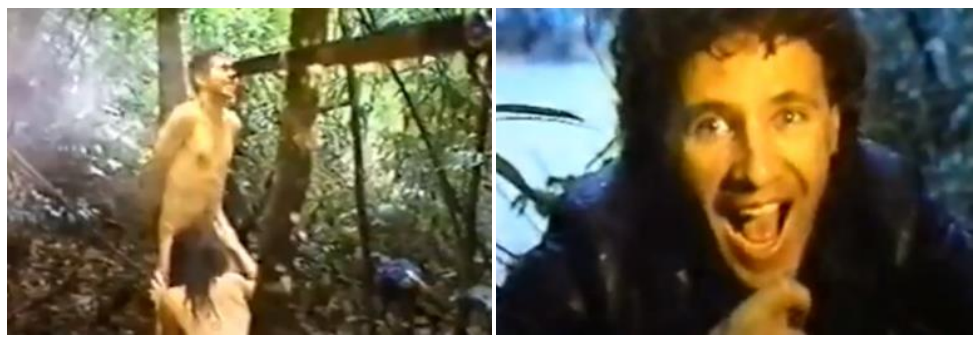

Figura 1 - Cenas de "No Calor do Buraco" (1986).

Além disso, a virilidade do protagonista é reforçada pela sede de vingança e de justiça em relação a outros homens que lhe causaram algum prejuízo financeiro ou emocional. No filme em

reafirmação da virilidade em um contexto de crise: "Trabalhar é pra otário e, se esse país é uma foda, então vamos foder” (Lucena, 2013). 
questão, após ter a namorada estuprada, o protagonista - um capataz interpretado por Baby - busca emprego numa fazenda em que é traído pelos seus colegas. Após escapar de uma emboscada, ele pretende aniquilar o proprietário da fazenda e seus funcionários (Roveri, 2007).

Em "Emoções sexuais de um jegue", Baby interpreta Gavião, um presidiário portador do vírus HIV. Ao fugir da prisão, o personagem arrasta uma mulher para um local no qual existe um caixão. "Esse é o caixão do amor. Estou com fome de sexo. Vou comer seu cu aqui dentro", diz Gavião para a mulher, ao carrega-la até o caixão e a infectar com o vírus, como se vê na sequência de imagens da Figura 2. A violência contra a mulher dáse não só por meio do estupro, mas da contaminação do corpo dela, o que reforça o controle exercido pelo homem sobre esse corpo.
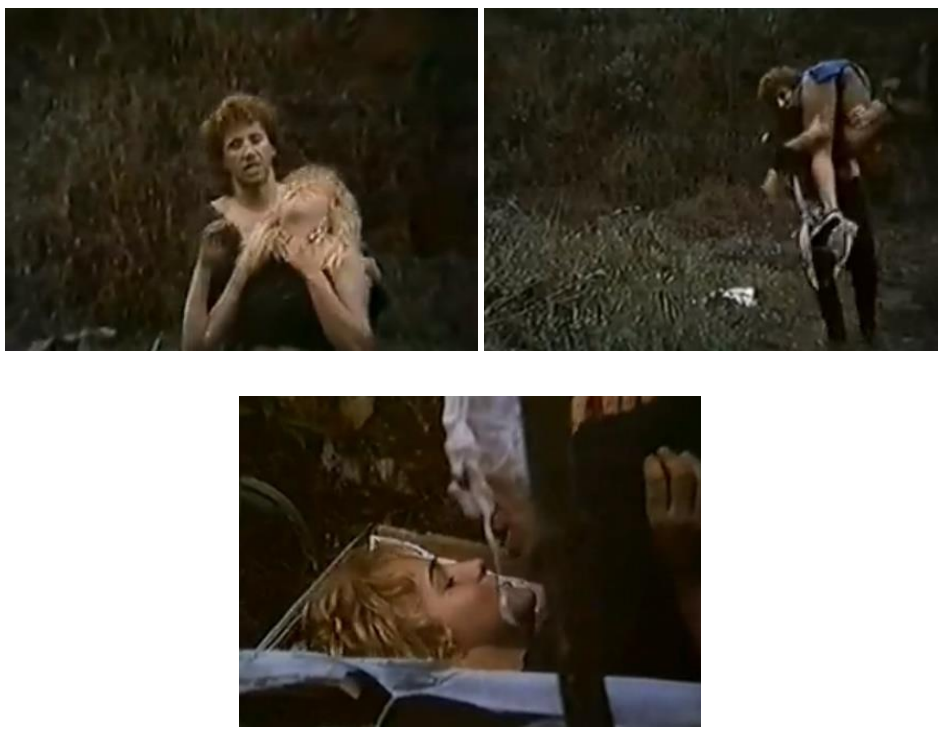

Figura 2 - Cenas de "Emoções sexuais de um jegue" (1986).

No mesmo filme, Gavião ameaça socar a barriga de sua mulher pelo fato de ela ter sido engravidada pelo pai do 
presidiário enquanto ele estava encarcerado. $\mathrm{O}$ personagem deseja se vingar do pai - o Velho Paçoca, concebido como um "velho caquético e tarado" - e punir a mulher pelo adultério. Ela é morta depois de ter sua cabeça coberta por um saco e Gavião atear fogo no casebre onde ela morava. A dominação viril incide não só sobre o corpo da mulher, mas também de outros homens, como o próprio pai. Ao saber que seu pai também havia engravidado a própria filha, Gavião sai em busca dele, na defesa de sua irmã. "Velho fedido. Eu vou comer o cu daquele velho filho da puta", diz ele. Como se vê na Figura 3, Gavião também obriga um médico a chupar uma ferida no seu braço visando a infectá-lo com o vírus HIV, pois tal médico não tinha cumprido a promessa de curá-lo da doença (Mendes, 2007).

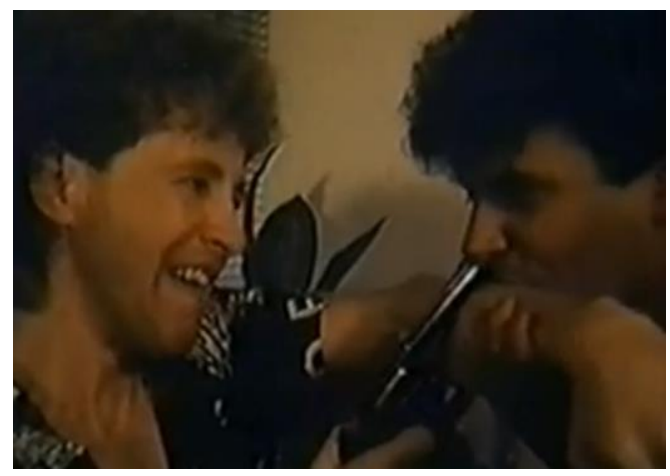

Figura 3 - Cena de "Emoções sexuais de um jegue" (1986).

A figura do protagonista prisioneiro e justiceiro é retomada em "Meninas, Virgens e P... (Troca de Óleo)", em que o sádico Rombo deixa a prisão buscando vingar-se de todos os seus comparsas, em especial do marginal D.K.V., que teria roubado seu dinheiro. A virilidade do personagem é destacada numa vida permeada por sexo, orgias e desfrute carnal (Carneiro, 2007).

Já a mulher é relegada nessas produções à objetificação, tendo sua representação construída como a de um instrumento de prazer ao homem e até mesmo a de um animal. Em "Emoções sexuais de um jegue", uma personagem aparece masturbando um 
jegue falante. Na mesma obra, em face da impossibilidade de se inserir uma câmera no interior de uma vagina, Baby pediu que o ator enfiasse o pênis em um pedaço de carne a fim de registrar o que seria a ejaculação vista do interior da vagina (Mendes, 2007). O corpo da mulher - mais especificamente seus órgãos sexuais - é colocado analogamente a um pedaço de carne. No caso de "Meninas, Virgens e P... (Troca de Óleo)", poucas atrizes seguem os padróes tradicionais de beleza e, nas cenas de sexo explícito, em geral, se colocam em posição desvalorizada em relação ao homem. "Ai, me chama de vagabunda", diz uma das personagens durante uma das cenas. Tratamentos como "puta" e "piranha" proferidos pelos homens às mulheres, em especial durante as cenas de sexo explícito - são frequentes ao longo desse filme e também do filme "No calor do buraco", como se vê nas referências à personagem retratada na Figura 4, durante o filme.

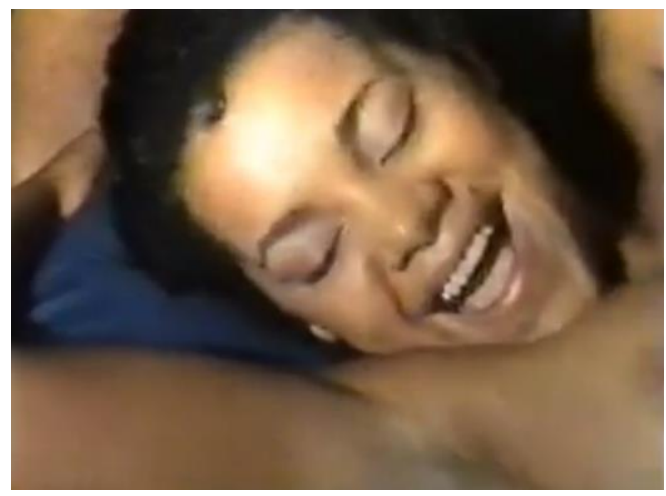

Figura 4 - Cena de "No calor do buraco" (1986).

Tais mulheres mostram-se capazes de atitudes extremas, como a realização de sexo oral profundo, colocando grandes pênis eretos na boca. Em outra cena de "Meninas, Virgens e P... (Troca de Óleo)", o antagonista do personagem de Baby é incentivado por seu parceiro a estuprar uma mulher. Mulheres que não delatam os homens ligados a elas para os rivais - seja o personagem de Baby ou seus antagonistas - são violentadas $e$ 
mortas por enforcamento ou a facadas, como fica claro na Figura 5 (Carneiro, 2007).

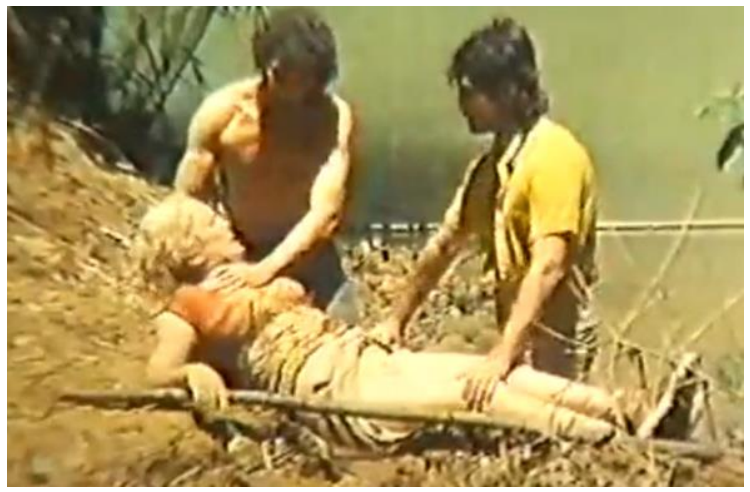

Figura 5 - Cena de "Meninas, Virgens e P... (Troca de Óleo)" (1986).

Em "No calor do buraco", o personagem de Baby mata uma mulher que o acompanha ao longo da narrativa $e$, ao manter uma relação sexual com ela morta, afirma para a câmera que "transar com uma morta é uma experiência arrepiante" (Roveri, 2007), mostrando-se indiferente à própria vida da mulher.

Quanto à construção das representações de homens homossexuais e travestis, em "Emoções sexuais de um jegue" (Mendes, 2007), por exemplo, um homossexual é morto em uma boate durante uma orgia com homens gays e travestis, com o protagonista abrindo seu tórax com uma motosserra. No filme, a representação do homossexual vem ligada ao uso de roupas e à realização de trejeitos femininos, como no personagem de blusa amarela e saia, na Figura 6. 


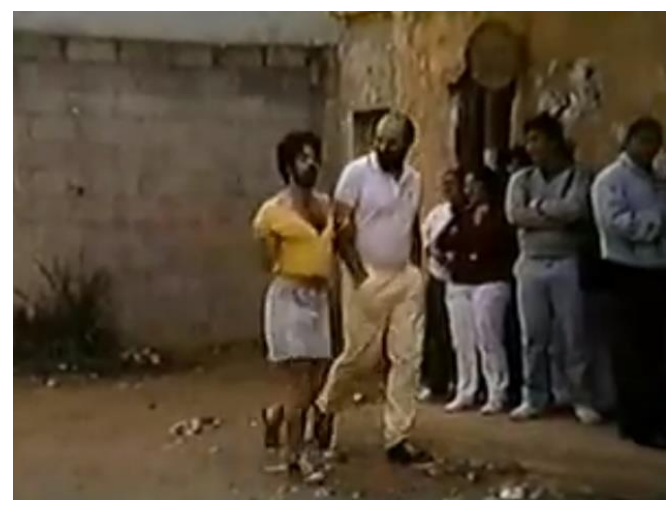

Figura 6 - Cena de "Emoções sexuais de um jegue" (1986).

A sodomização de outros homens aparece também como forma de afirmação da própria masculinidade. Os dois homens que aparecem na figura acima são repreendidos por um policial, que, ao levá-los para uma mata fechada, é sodomizado por eles, ainda que se afirme como "homem macho", usando um babydoll por baixo da farda, como se vê na Figura 7.

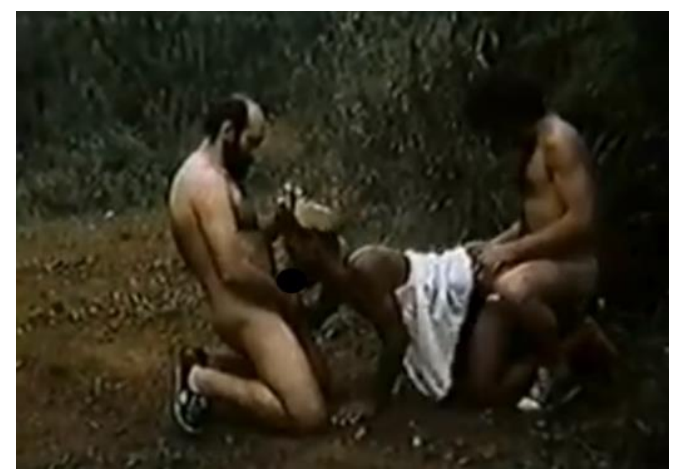

Figura 7 - Cena de "Emoções sexuais de um jegue" (1986).

No mesmo filme, as travestis são representadas a partir de trejeitos exagerados com roupas, acessórios, maquiagens $e$ penteados extravagantes associados ao universo feminino. $\mathrm{O}$ mesmo ocorre em "No calor do buraco", como se vê na Figura 8: 

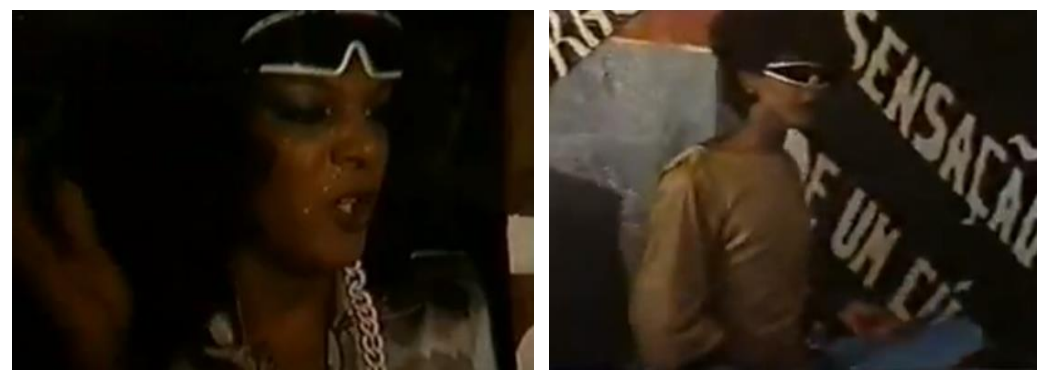

Figura 8 - Cenas de "Emoções sexuais de um jegue" (1986) e "No calor do buraco" (1986), respectivamente.

Em "Meninas, Virgens e P... (Troca de Óleo)", o protagonista e seus parceiros na prisão obrigam, para o escracho $e$ o deboche, em busca de diversão na vida no cárcere (Figura 9), um encarcerado "afeminado" - chamado de "bichona" - a fazer sexo oral e praticar sexo anal com um detento. Ao defecar durante o ato, tal homossexual é rejeitado pelos demais detentos e chamado de "porco".

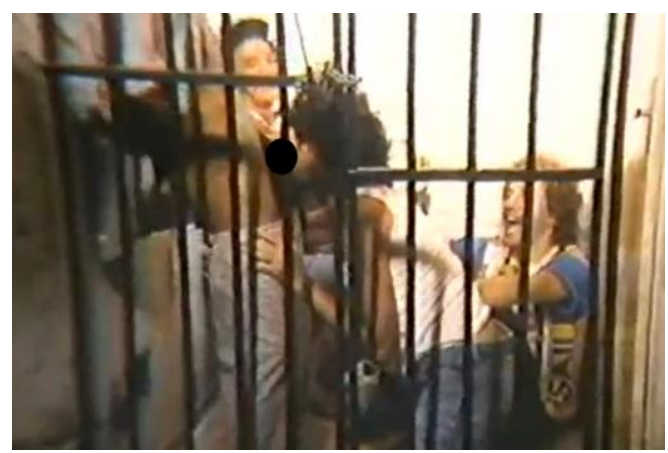

Figura 9 - Cena de "Meninas, Virgens e P... (Troca de Óleo)" (1986).

Em outro momento, já fora da prisão, o personagem de Baby obriga mais um "afeminado" - acusado de roubar o dinheiro do protagonista - a praticar sexo oral em um dos seus parceiros e depois a "sentar na boneca" - no pênis - do mesmo 
homem. Mais adiante, o personagem, ao observar dois homens bêbados fazendo sexo no mato, ridiculariza-os e ainda emite um comentário de cunho racista: "Tinha que ser preto mesmo". Depois, mata-os enfiando um casco de garrafa quebrado na garganta de cada um e os chama de "porcos" por terem "ficado com a sua grana".

\section{Discussão e análise}

A perversão da pornochanchada estava na ruptura de visões tradicionais acerca de temas como o matrimônio e a religiosidade a partir da sátira, da vulgarização e do recondicionamento dos valores morais. Entretanto, trazer temas controversos com a exploração de elementos eróticos e sexuais não necessariamente pressupunha a desestabilização de estigmas e preconceitos relacionados a gênero e sexualidades. $\mathrm{O}$ estereótipo viril continuava associado à potência muscular e à compulsão sexual, enquanto a mulher era construída como um objeto para a satisfação do desejo masculino, $e$ homens homossexuais $e$ travestis eram tomados a partir de estereótipos construídos por trejeitos efeminados e pela obsessão por sexo. Como apontado acima, ainda que o "male gaze" (Mulvey, 1999) - conceito já exaustivamente trabalhado pela literatura feminista - apresente-se nas produções de Sady Baby, ele vem permeado por particularidades culturais brasileiras, que remetem a formas específicas de construção de masculinidades, feminilidades $e$ travestilidades na sociedade brasileira. $\mathrm{O}$ homem é ligado à figura do marginal de grandes centros urbanos do país, do capataz ou do sertanejo, enquanto a mulher é associada à imagem da "vagabunda" ou "prostituta", demonizada pelo discurso moralizante dos setores mais reacionários e conservadores da sociedade brasileira. A travesti aparece associada também à prostituição e à compulsão sexual, noção disseminada na sociedade brasileira ao longo das décadas de 1960 e 1970, por atenderem a desejos mais secretos de homens que se veem como 
heterossexuais e vivem a sexualidade com as travestis nos espaços recolhidos e privados.

Nesse sentido, mais do que meramente uma reprodução da sexploitation norte-atlântica, a pornochanchada vai na direção do argumento de Abreu $(1996,2006)$ de que, ao incorporar elementos dessas produções estrangeiras, ela os mesclou a signos existentes na cultura brasileira - como as chanchadas - $e$ criou versões locais que travavam um diálogo tanto com os códigos culturais que embasaram as condições da experiência estética no Brasil, como com a cultura de consumo de imagens eróticas e de sexo explícito. Em tal contexto, a permanência dos estigmas faz com que a maior parte das produções não transgrida, assim, as condições já conhecidas de representação a partir das categorizações biológicas $e$ da força cultural das representações de identidades de gênero $e$ de orientações sexuais (Amaral, 2016).

Nos filmes examinados, as representações são construídas a partir da semelhança ou da identificação por parte do público de aspectos ligados a gênero, raça, orientação sexual ou condição social, $e$ as alteridades são definidas com base na exclusão desses fatores de aproximação (Carrasco; Oliveira, 2016). Mesmo trazendo as diferenças para a tela, os filmes de Sady Baby reiteram a centralidade e o domínio do homem heterossexual branco, que subjuga e domina mulheres, homossexuais, travestis e também homens não brancos, vide o comentário que associa pejorativamente a raça negra à homossexualidade em "Meninas, Virgens e P... (Troca de Óleo)". Também é possível verificar na produção examinada, como aponta Cruz (2016a), que predomina o olhar masculino nas representações femininas presentes nas narrativas, de forma que a mulher continua sendo retratada como fonte de desejos sexuais que ajudam a compor um espetáculo extremo do bizarro. Tal mulher é contemplada não só pelos personagens masculinos, como também pelo homem espectador, que se identifica com o protagonista masculino e domina a ação sob seu olhar erótico e pornográfico. O homem heterossexual representado de maneira relativamente uniforme nas obras de Sady Baby - mantém uma identidade estável nas obras analisadas 
em relação à fase softcore da pornochanchada, sendo colocado como "malandro", sedutor, vingativo e hiperviril, ao passo que os "mal sucedidos" são retratados como "cornos", "tarados" ou impotentes. Além de realizarem comentários machistas, eles também têm falas racistas, misóginas e homofóbicas. Diante das construções sociais existentes sobre as identidades homoeróticas à época dos filmes de Baby, a homossexualidade masculina, bem como as travestis, eram tomadas de maneira caricata, como colocam Cruz (2016a) e Pires (2016).

Nesse sentido, a produção de Sady Baby enquadrava-se no tom de deboche, com personagens caricatos e situações jocosas típicos da pornochanchada, mas, como aponta Freitas (2004) em relação às demais produções do gênero, utilizava mulheres sexualmente disponíveis e "desinibidas" que apelavam diretamente ao sonho erótico do público masculino. Ainda que em seus filmes o diretor explorasse relações sexuais entre homens $e$ entre homens e travestis, a matriz heteronormativa era preservada, na medida em que a heterossexualidade era concebida como um dos elementos definidores da masculinidade do protagonista e de outros homens nessas produções. Eles não viam suas posições enquanto predadores viris serem ameaçadas, uma vez que se mantinham como os ativos nas relações sexuais e os dominadores dos corpos de homens vistos como mais frágeis e de travestis. Mesmo não negando o trânsito de homens pelas sexualidades de outros (Freitas, 2004), as obras de Sady Baby reforçavam o estereótipo do "macho" heterossexual a partir da estigmatização do homem passivo e da travesti em posições de aberração e de abjeção. Os personagens masculinos - notavelmente o próprio protagonista - eram tipicamente retratados como esperto, cafajeste, malandro e bem-sucedido sexualmente, sendo a fraqueza delegada a idosos ou homossexuais, que eram, em geral, ridicularizados (Carrasco; Oliveira, 2016). A representação de uma relação homoerótica entre homens ou de homens com travestis assumia um cunho irônico e satírico, que contribuía para estigmatizar e desmoralizar essas práticas (Trevisan, 2000), como se observa nas produções de Sady Baby. As obras examinadas 
mostram excessos de toda ordem, bem como excrementos $e$ fluidos que ajudam a compor o que Pelúcio (2007) aponta como o "material excitante do bizarro". Entretanto, como sinaliza a autora, os corpos $e$ os prazeres de mulheres, travestis $e$ homens homossexuais em cena somente eram legítimos como aberrações, não havendo outras possibilidades de existência, preservando-se os limites que tornam a "normalidade" o padrão desejável (Pelúcio, 2007).

\section{Considerações finais}

A pornochanchada trazia um cinema supostamente despretensioso, mas transcendia a alienação na medida em que promovia questionamentos da moral e dos "bons costumes" pregados pelos setores mais conservadores da sociedade brasileira. Enquanto movimento, ela englobava aquilo que era criticado por uma elite cultural, satirizando valores sociopolíticos reacionários impostos pelo regime militar e sustentados por grande parte das classes médias. A tamanha identificação do público fez com que rapidamente as produções do gênero se consolidassem na preferência das plateias populares, fazendo com que a sociedade fortemente reprimida encontrasse nelas uma forma de realização de desejos e de obtenção de prazer diante de uma moral opressora. Entretanto, tais produções também representavam o machismo e a misoginia da maior parte da população, a objetificação do corpo feminino e o sexo como afirmação da superioridade de uma masculinidade hegemônica heterossexual em relação a outras masculinidades (Rossini, 2016).

Nesse sentido, a pornochanchada continuava reiterando dicotomias entre homens $e$ mulheres, heterossexuais $e$ homossexuais, de forma a preservar intactos preceitos misóginos, patriarcais e homofóbicos vigentes na época (Trevisan, 2000). Apesar de seu caráter transgressor em vários aspectos, a fase hardcore desse gênero - que teve em Sady Baby um de seus expoentes - perpetuava preconceitos por estar ainda fincada em elementos da moral conservadora. Aos preconceitos baseados em 
identidades de gênero e orientações sexuais, juntavam-se aqueles associados à raça e à origem (Cruz, 2016a).

\section{Referências bibliográficas}

ABREU, Nuno Cesar. $O$ olhar pornô: A representação do obsceno no cinema e no vídeo. Campinas, Mercado das Letras, 1996.

ABREU, Nuno Cesar. Pornochanchada. In: RAMOS, Fernão; MIRANDA, Luiz Felipe (org.). Enciclopédia do cinema brasileiro. São Paulo, Editora SENAC, 2000.

ABREU, Nuno Cesar. Boca do Lixo: cinema e classes populares. Campinas, Editora da UNICAMP, 2006.

AMARAL, Muriel. As representações da perversão e o estereótipo no filme "Macho, Fêmea e Cia. - A vida erótica de Caim e Abel". In: BERTOLLI FilHo, Claudio; AmARAl, Muriel E.P. (org.) Pornochanchando: em nome da moral, do deboche e do prazer. São Paulo, Cultura Acadêmica, 2016, pp.121-138.

BERTOLLI FILHO, Claudio. Um confronto esquecido: pornochanchada X moral e civismo. In: BERTOLLI FILHO, Claudio; AMARAL, Muriel E.P. (org.). Pornochanchando: em nome da moral, do deboche e do prazer. São Paulo, Cultura Acadêmica, 2016, pp.15-39.

BerTolli FILHO, Claudio; AMARAL, Muriel E.P. Apresentação: Pornochanchada como discurso do desejo. In: BerTOLLI FILHO, Claudio; AMARAL, Muriel E.P. (org.). Pornochanchando: em nome da moral, do deboche e do prazer. São Paulo, Cultura Acadêmica, 2016, pp.7-10.

Bertolli FilHo, Claudio; TAlAmONI, Ana Carolina Biscalquini. O ‘Sacana Coça-Saco Tropical' e o Homo brasilis: O discurso fundador do Brasil segundo um 'professor' alemão em Bonitas e Gostosas. In: MARQUES, José Carlos (ed.). A Copa das Copas? Reflexões sobre o Mundial de Futebol de 2014 no Brasil. São Paulo, Edições Ludens, 2015, pp.311-333.

BOURDIEU, Pierre. A dominação masculina. Rio de Janeiro, Bertrand Brasil, 2003. 
CARNEIRO, Gabriel. Meninas Virgens e P... (Troca de Óleo). Zingu!, 2007 [http://revistazingu.blogspot.com.br/2007/10/dsbmeninasvirgenseptrocadeoleo.html - acesso em: 23 nov. 2017].

CARRASCO, Vinicius; OliveIRA, Bruno Jareta de. Pornochanchada, paródia e representações sociais - Análise filmica de "Bacalhau", "Nos tempos da vaselina" e "Um pistoleiro chamado Papaco". In: BerTOlLI FILHO, Claudio; AMARAL, Muriel E.P. (org.). Pornochanchando: em nome da moral, do deboche e do prazer. São Paulo, Cultura Acadêmica, 2016, pp.195-220.

Cruz, Lívia Maria Pinto da Rocha do Amaral. (Nem) tudo puta e viado: uma análise dos estereótipos presentes no cinema erótico brasileiro (1969-1982). Dissertação (Mestrado em Multimeios), Instituto de Artes, Universidade Estadual de Campinas, Campinas, 2016a.

CRUZ, Lívia Maria Pinto da Rocha do Amaral. O Sexploitation tupiniquim: as Pornochanchadas brasileiras. Argus-a, vol. V, nº. 21, 2016b, s.p.

FREITAS, Marcel de Almeida. Entre estereótipos, transgressões e lugares comuns: notas sobre a pornochanchada no cinema brasileiro. Intexto, Porto Alegre, $n^{\circ} 10,2004$, pp.65-91.

GERACE, Rodrigo. Cinema Explícito: representações cinematográficas do sexo. São Paulo, Perspectiva, Edições Sesc São Paulo, 2015.

GORFINKEL, Elena. "Indecent Desires": Sexploitation Cinema, 1960s Film Culture and the Adult Film Audience. Tese (Doutorado), New York University, Nova Iorque, 2008.

GORFINKEL, Elena. The Body's Failed Labor: Performance Work in Sexploitation Cinema. Framework: The Journal of Cinema and Media, vol. 53, n 1, 2012, pp.79-98.

GREEN, James N. Além do Carnaval: a homossexualidade masculina no Brasil do século XX. São Paulo, Editora UNESP, 2000.

GUBERNIKOFF, Giselle. A imagem: representação da mulher no cinema. Conexão - Comunicação e Cultura, vol. 8, nº. 15, 2009, pp.65-77.

KAPLAN, Elizabeth Ann. A mulher e o cinema: os dois lados da câmera. Rio de Janeiro, Rocco, 1995. 
KLANOVICZ, Luciana Rosar Fornazari; CoRRÊA, Willian Bruno. Gênero, censura e pornochanchada no cinema brasileiro. In: BERTOLLI FILHO, Claudio; AmARAL, Muriel E.P. (org.). Pornochanchando: em nome da moral, do deboche e do prazer. São Paulo, Cultura Acadêmica, 2016, pp.63-81.

LAMAS, Caio. A censura à pornochanchada: o caso de "Anjo Loiro". In: BERTOlli FIlHO, Claudio; AMARAL, Muriel E.P. (org.). Pornochanchando: em nome da moral, do deboche e do prazer. São Paulo, Cultura Acadêmica, 2016, pp.41-61.

LEITE JR., Jorge. Das maravilhas e prodígios sexuais: pornografia bizarra como entretenimento. São Paulo, Annablume, 2006.

LOPES, Marcelo. A breve história da pornochanchada. Sintoma de Cultura, 11 out. 2012 [http://sintomadecultura.com.br/coluna01/cinema-e-audiovisual-coluna-01/a-breve-historia-dapornochanchada/ - acesso em: 13 nov. 2017].

LUCENA, Matias Rech de. Entrevista: Sady Baby. Vice, 6 mar. 2013 [https://www.vice.com/pt_br/article/8q4q7a/entrevista-sady-baby acesso em: 23 nov. 2017].

MENDES, Gio. Emoções sexuais de um jegue. Zingu!, 2007 [http://revistazingu.blogspot.com.br/2007/10/dsbemocoessexuaisdeumjegue.html - acesso em: 23 nov. 2017].

Moreno, Antonio. A personagem homossexual no cinema brasileiro. Rio de Janeiro, Editora da UFF; Funarte, 2001.

Mulvey, Laura. Visual Pleasure and Narrative Cinema. In: BRAUDY, Leo; COHEN, Marshall (ed.). Film Theory and Criticism: Introductory Readings. Nova Iorque, Oxford UP, 1999, pp.833-44.

PADOVANI, Gustavo. "Garotas da van": fragmentos da pornochanchada na cultura participativa. In: BERTOLLI FILHO, Claudio; AMARAL, Muriel E.P. (org.). Pornochanchando: em nome da moral, do deboche e do prazer. São Paulo, Cultura Acadêmica, 2016, pp.275-291.

PELÚCIO, Larrisa. As maravilhas do sexo que ri de si mesmo. cadernos pagu (29), Campinas-SP, Núcleo de Estudos de GêneroPagu/Unicamp, 2007, pp.481-488.

PIRES, Annelize. A representação da travesti na pornochanchada: "Novas sacanagens do Viciado em C". In: BerTOlLi FILHO, Claudio; AMARAL, 
Muriel E.P. (org.). Pornochanchando: em nome da moral, do deboche e do prazer. São Paulo, Cultura Acadêmica, 2016, pp.259271.

ROSSINI, Renan Siqueira. Pornochanchada: um sintoma brasileiro. In: Bertoli FilHo, Claudio; AmARAl, Muriel E.P. (org.). Pornochanchando: em nome da moral, do deboche e do prazer. São Paulo, Cultura Acadêmica, 2016, pp.83-100.

ROVERI, Fernando. No calor do buraco. Zingu!, 2007 [http://revistazingu.blogspot.com.br/2007/10/dsbnocalordoburaco.html - acesso em: 23 nov. 2017].

SALES FILHO, Valter Vicente. Pornochanchada: doce sabor da transgressão. Comunicação \& Educação, vol. 2, n. 3, 1995, pp.6770.

SELIGMAN, Flávia. Um certo ar de sensualidade: o caso da pornochanchada no cinema brasileiro. Sessões do Imaginário, $n^{\circ} .9$, 2003, pp.38-40.

SIMÕES, Inimá. Sexo à brasileira. Alceu, vol. 8, nº 15, 2007, pp.185-195.

STERNHEIM, Alfredo. Cinema da Boca: dicionário de diretores. São Paulo, Imprensa Oficial, 2005.

TREviSAn, João Silvério. Devassos no paraíso: a homossexualidade no Brasil, da colônia à atualidade. Rio de Janeiro, Record, 2000.

VergarA, Silvia. Métodos de pesquisa em Administração. São Paulo, Atlas, 2012.

WATSON, Paul. There's no accounting for taste: Exploitation cinema and the limits of film theory. In: CARTMELL, Deborah; HUNTER, I. Q.; KAYE, Heide; WHELEHAN, Imelda (ed.) Trash Aesthetics. Popular culture and its audience. Londres, Pluto Press, 1997, pp.66-87.

WILLIAMS, Linda. Pornography, porno, porn: thoughts on a weedy field. Porn Studies, vol. 1, n. 1-2, 2014, pp.24-40. 